\title{
The Atlantic elements in the Swiss flora: distribution, diversity, and conservation status
}

\author{
Gregor Kozlowski · Sandra Bürcher · Matthieu Fleury • \\ Fanny Huber
}

Received: 12 August 2008/Accepted: 14 November 2008/Published online: 3 December 2008

(C) Springer Science+Business Media B.V. 2008

\begin{abstract}
The purpose of this study was to examine the composition, distribution, ecology, and conservation status of the Atlantic elements of the Swiss flora. About 195 Atlantic and 80 Mediterranean-Atlantic vascular plant species of the European flora have been used as the basis for our analysis. The complete list of 3,143 taxa has been used as the reference for the Swiss flora. The distributions of the species are illustrated in coincidence maps based on the computer database of the Data Centre of the Swiss Flora in Geneva, Switzerland. Our study demonstrates clearly that the Atlantic flora of Europe requires a new biogeographical appraisal. The Swiss flora comprises 66 Atlantic and MediterraneanAtlantic taxa, which are taxonomically and ecologically highly diverse. Switzerland contains $44 \%$ of all European Sub-Atlantic plants. This confirms the Sub-Atlantic geographical position of Switzerland. Only one Eu-Atlantic species growing in Switzerland, Vicia orobus, can be classified as native with certainty. This species is critically endangered and merits the highest conservation priority. Although a very alpine country, Switzerland has a relatively large number of Mediterranean-Atlantic species. The Atlantic and Mediterranean-Atlantic plants are a very threatened group in Switzerland, with wetland plants the most imperilled ecological group.
\end{abstract}

Keywords Biogeographical regions · Floristic elements · Linnean shortfall · Peripheral populations · Range margin - Red list - Switzerland · Wallacean shortfall

Electronic supplementary material The online version of this article (doi:10.1007/s10531-008-9531-0) contains supplementary material, which is available to authorized users.

G. Kozlowski $(\bowtie) \cdot$ M. Fleury

Department of Biology and Botanic Garden, University of Fribourg, Ch. du Musée 10,

CH-1700 Fribourg, Switzerland

e-mail: gregor.kozlowski@unifr.ch

S. Bürcher · M. Fleury · F. Huber

Department of Geosciences-Geography, University of Fribourg, Ch. du Musée 4, CH-1700 Fribourg,

Switzerland 


\section{Introduction}

One of the most important tasks of conservation biogeography is the identification and delimitation of floristic regions (areas characterized by similar flora) and floristic elements (assemblies of species with similar distributions) (Born et al. 2007; Finnie et al. 2007). The Atlantic floristic region of Europe has a long history of exploration. Notions of its distinctiveness can be found as early as the beginning of the nineteenth century (e.g., de Candolle 1808). However, its exact boundaries, like those of any biogeographical region, cannot be drawn with absolute precision (Meusel et al. 1965; Jäger 1968; Hopkins and Buck 1995; Born et al. 2007). Thus, the maps and descriptive delimitations of the Atlantic region in Europe differ significantly (e.g., Drude 1892; Flahault 1901; Braun-Blanquet 1928; Walter 1954; Meusel et al. 1965; Jäger 1968, 1970; Takhtajan 1986; Dahl 1998). Nowadays, the European Environmental Agency's map of its biogeographical regions is widely used (EEA 2005; Fig. 1). It divides the European continent into 12 regions and was created based on a map of the natural vegetation of Europe (ETCBD 2006; Finnie et al. 2007). The Atlantic region in Europe is not a homogeneous unit. Hopkins and Buck (1995) divided it into two sectors with distinct topographies and land-use histories: (1) the North European Plain (west Jutland, The Netherlands, North Germany, Flanders/Brussels, northeast France, south-east England), with relatively flat land surfaces rarely reaching elevations above $300 \mathrm{~m}$ a.s.l; and (2) the "Celtic Fringe" (Ireland, Wales, Scotland, north and west England, Brittany, Landes in France, Galicia in Spain, and northern Portugal), with a more ragged topography, with true local alpine vegetation at 2,000 $\mathrm{m}$ a.s.l. and above (Duckworth et al. 2000). A much more detailed division of the Atlantic region, based on its vegetation and floristic characteristics, can be found in Meusel et al. (1965). In other biogeographical regions of Europe and in the Mediterranean, there are also many isolated areas with Atlantic characteristics. East of the Massif Centrale in France (Hopkins and Buck 1995), Lusatia in eastern Germany (Krausch 1985), and Kroumirie in Tunisia (Braun-Blanquet 1953) can be considered exclaves of the Atlantic/Oceanic conditions. The most distinctive feature of the Atlantic region in Europe is its climate, influenced by air masses originating over the ocean, as well as by the warm waters of the Gulf Stream (Hopkins and Buck 1995). These circumstances result in less extreme temperatures and higher levels of precipitation than those of continental Europe. The Atlantic region is thus characterized by mild wet winters and cool moist summers (Duckworth et al. 2000).

The listing of vascular plants belonging to the Atlantic floristic element in Europe has a very long history (e.g., Braun-Blanquet 1923; Allorge 1924; Steffen 1935; Matthews 1937; des Abbayes 1945; Schmid 1945; Fournier 1946; Walter 1954; Darimont et al. 1962; Dupont 1962; Roisin 1969). However, the numbers of taxa listed in these works vary between 50 (Walter 1954) and more than 300 (Dupont 1962). Many authors, especially in central Europe, refer to "Atlantic" taxa as those that have their maximum occurrence frequency in Atlantic Europe, without taking into account their global distributions (e.g., Czeczott 1926; Krausch 1985; Pietsch 1985; Preston and Hill 1997). The unclear taxonomic divisions of many genera of European plants are responsible for this discrepancy. The most rigorous and thus the most biogeographically correct are the lists of Dupont (1962) and Roisin (1969).

Roisin (1969) divides the Atlantic floristic element of Europe into three subelements: (1) the Eu-Atlantic species, with a distribution restricted to the Atlantic biogeographical region and with only a few occurrences (if any) outside it; (2) the Sub-Atlantic species, with its maximum frequency within the Atlantic region, but also present in continental Europe and the Mediterranean; and (3) the Eury-Atlantic species, with their distribution 


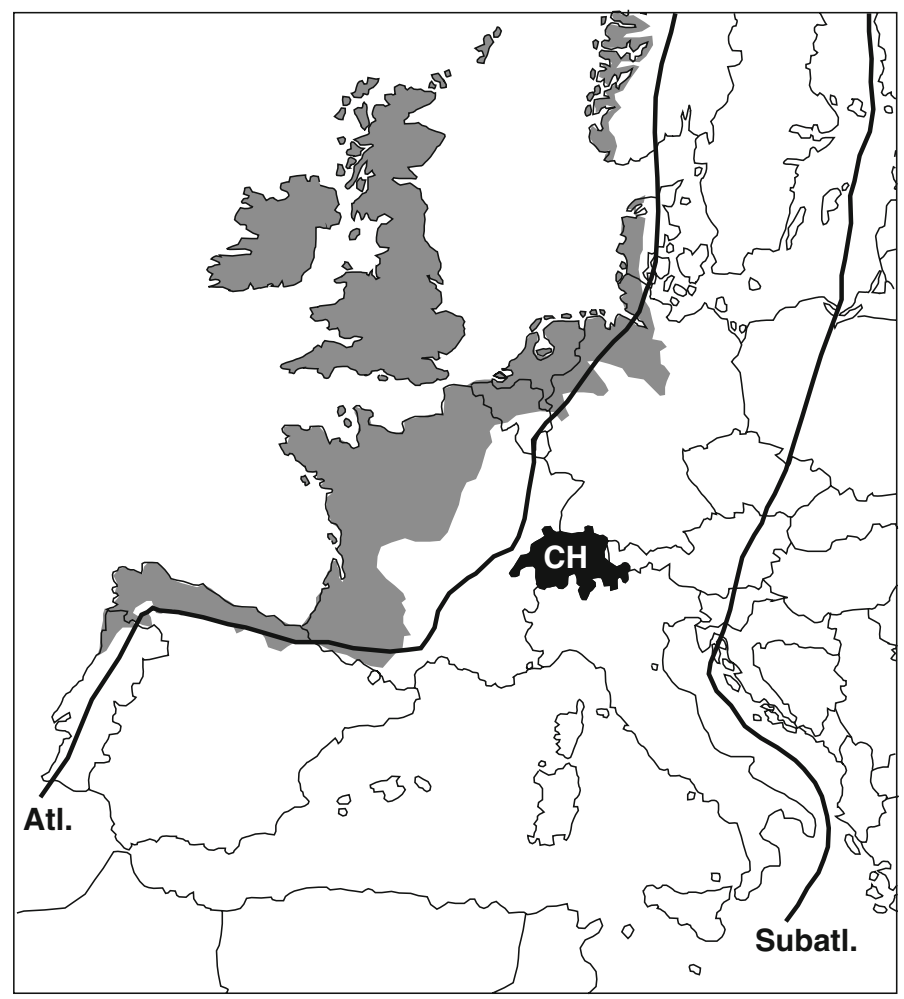

Fig. 1 Atlantic biogeographical region of Europe. Gray area delimitation of the Atlantic region of the European Environment Agency (EEA 2005). Black lines delimit the Atlantic (Atl.) and Sub-Atlantic (Subatl.) zones in Europe, according to Preston and Hill (1997). CH: Switzerland

restricted to the Atlantic regions of both Europe and North America. Roisin (1969) also listed 80 species with a Mediterranean-Atlantic distribution. This is a very problematic group, which has not yet been studied in a comprehensive manner. The historical biogeography of this group is not well understood (Jäger 1970; Rivas-Martinez 1990; Ojeda et al. 1998; Preston and Hill 1997; Preston and Arnold 2006). Moreover, most of these plants occur in North Africa and/or in the Near East, outside the geographical territory of the Flora Europaea (Tutin et al. 1993). The detailed biogeographical analysis of this group is therefore very difficult.

Recent works on the Atlantic biogeographical region and its flora are extremely rare and mainly concentrate on small geographic areas and/or a chosen taxonomic unit (e.g., Ojeda et al. 1998; Crawford 2000; Duckworth et al. 2000; Preston and Hill 1997; Preston and Arnold 2006). The majority of the Atlantic elements are west European and/or Mediterranean endemics (Dupont 1962; Cook 1983). Some of them have been shown to have existed in Europe for several million years (e.g., paleoendemic Baldellia ranunculoides, Kozlowski et al. 2008). Our inadequate biogeographical knowledge of this plant group might have dramatic negative consequences for priorities and conservation efforts in the near future.

The purpose of this study was to examine the distribution, taxonomic and ecological diversity, and conservation status of the Atlantic and Mediterranean-Atlantic elements in 
the Swiss flora, an appraisal not previously undertaken. This paper should serve as a trigger for more intensive future biogeographical and conservation studies of the Atlantic region and its unique flora in Europe and the Mediterranean.

\section{Materials and methods}

The list of Roisin (1969), containing 195 Atlantic and 80 Mediterranean-Atlantic vascular plant species of the European flora, was used as the basis for our analysis. Roisin's study is a critical compilation of all the important previous works (e.g., Braun-Blanquet 1923; Allorge 1924; Steffen 1935; des Abbayes 1945; Fournier 1946; Walter 1954; Darimont et al. 1962; Dupont 1962). The taxonomic nomenclature of Roisin (1969) was adapted according to the taxonomic database of Flora Europaea at the Royal Botanic Garden of Edinburgh, UK (http://rbg-web2.rbge.org.uk; see also Appendix S1 in Supplementary Material). For the Swiss flora, the red list of vascular plants (Moser et al. 2002), enumerating 3,143 angiosperms and pteridophytes, has been used as a reference. Only native and naturalized plants of European origin (i.e., European species occurring in Switzerland since the sixteenth century) have been used for the analysis. Neophytes from other continents have been excluded. For Switzerland, the Synonymy Index of the Swiss Flora (ISFS 2005) was also used for floral nomenclature and family affinities.

The distributions of the species are illustrated in coincidence maps showing the proportion of each sub-element in grid squares. The maps are based on the computer database managed by the Data Centre of the Swiss Flora (CRSF) in Geneva, Switzerland (http://www.ville-ge.ch/cjb/rsf). The Centre holds all known vascular plants that occur in Swiss territory, based on (1) recent observations by the Centre (1982-2008, symbolized with black squares in the distribution maps), and (2) historical literature and/or herbarium data from the atlas of Welten and Sutter (1982) (symbolized with black dots). Each grid square represents $4 \times 4 \mathrm{~km}^{2}$. The division into ecological groups and into the red list categories followed Moser et al. (2002). The red list categories are those of the International Union for the Conservation of Nature and Natural Resources (IUCN 2001). Life forms follow the divisions of Raunkiaer (1934) and have been attributed to the Swiss flora by Landolt (1977).

\section{Results}

Switzerland and the Atlantic flora of Europe

Of the 195 Atlantic taxa described by Roisin, 49\% (95 taxa) belong to the Eu-Atlantic group, $45 \%$ (88 taxa) to the Sub-Atlantic group, and only 6\% (12 taxa) to the Eury-Atlantic group (Table 1, Appendix S1). The Swiss flora includes 44 Atlantic plant species (Table 1, Appendix 1). Four of these species belong to the Eu-Atlantic subelement (4\% of the $95 \mathrm{Eu}-$ Atlantic taxa of Europe). In Switzerland, there are a further 39 Sub-Atlantic species (44\% of the 88 European species in this group) and only one species from the Eury-Atlantic subelement. Of the 80 Mediterranean-Atlantic taxa of the European flora, 22 grow in Switzerland (27\%) (Table 1, Appendices 1 and S1). The Atlantic and MediterraneanAtlantic species present in Switzerland constitute $24 \%$ of the 275 European taxa of all the categories listed by Roisin (1969). Several other species from the list of Roisin have been observed in Switzerland. However, they are nonnative, not naturalized, having mainly 
Table 1 Atlantic and Mediterranean-Atlantic elements in the European and Swiss flora (for more details, see Appendices 1 and S1)

\begin{tabular}{lllllr}
\hline Region & $\begin{array}{l}\text { Eu-Atlantic } \\
\text { spp. }\end{array}$ & $\begin{array}{l}\text { Sub-Atlantic } \\
\text { spp. }\end{array}$ & $\begin{array}{l}\text { Eury-Atlantic } \\
\text { spp. }\end{array}$ & $\begin{array}{l}\text { Mediterranean- } \\
\text { Atlantic spp. }\end{array}$ & Total spp. \\
\hline Europe & 95 & 88 & 12 & 80 & 275 \\
Switzerland & 4 & 39 & 1 & 22 & 66 \\
\hline
\end{tabular}

escaped from cultivation, and are thus not included in the present analysis. This is the case for three Eu-Atlantic taxa: Hyacinthoides non-scripta, Saxifraga hirsuta, and Ulex europaeus, as well as one Sub-Atlantic species, Saxifraga hypnoides, and one MediterraneanAtlantic species, Alopecurus rendlei. Three more of Roisin's species of doubtful status in Switzerland (probably introduced) have also been excluded: Scutellaria minor (Sub-Atlantic), Lagurus ovatus, and Trifolium subterraneum (the two latter are Mediterranean-Atlantic).

\section{Taxonomic diversity}

The Atlantic and Mediterranean-Atlantic species of the Swiss flora belong to 38 families and 57 genera (Appendix 1). The majority of families (37\%) comprise only one member, and only seven families have more than two species: Scrophulariaceae sensu lato (six species), Liliaceae (four species), Asteraceae (four species), Fabaceae (four species), Cyperaceae (three species), Hypericaceae (three species), and Primulaceae (three species). Among all genera only eight (14\%) have more than one member: Hypericum has three species and the following genera two species each: Asplenium, Carex, Erica, Helleborus, Linaria, Orobanche, and Polygala.

\section{Distributions}

Figure 2 shows the distributions of the Atlantic and Mediterranean-Atlantic plants in Switzerland. Plants of the Eu-Atlantic subelement have a very scattered distribution pattern (Fig. 2a) and have been observed mainly in lowland sites on the Swiss Plateau and in southern Tessin (to ca. $600 \mathrm{~m}$ a.s.l.). The only exceptions occur in the Jura Mountains at about 1,200 m a.s.l. (Vicia orobus populations). The distribution of the Sub-Atlantic plants is shown in Fig. 2b. This group is widely distributed in Switzerland and is absent only from the higher alpine regions. The only Eury-Atlantic taxon in Switzerland, Rhynchospora fusca, has been mainly reported from the eastern Swiss Plateau and from Tessin (Fig. 2c). The Mediterranean-Atlantic subelement has its highest concentrations in the cantons of Geneva, Valais and Tessin, as well as in the surroundings of Basel and Neuchâtel (Fig. 2d).

\section{Ecological diversity}

Tables 2 and 3 show the ecological diversity of the investigated species. The majority of Atlantic and Mediterranean-Atlantic taxa (taken together) are woodland species (39\%), followed by wetland (24\%), pioneer (14\%), and weed/ruderal plants $(9 \%)$. The aquatics (two species), orophytes (three species), and plants of low-nutrient meadows (four species) are very poorly represented (Table 2). There are no nutrient-rich meadow plants in the Atlantic and Mediterranean-Atlantic elements of the Swiss flora. When the subelements of 


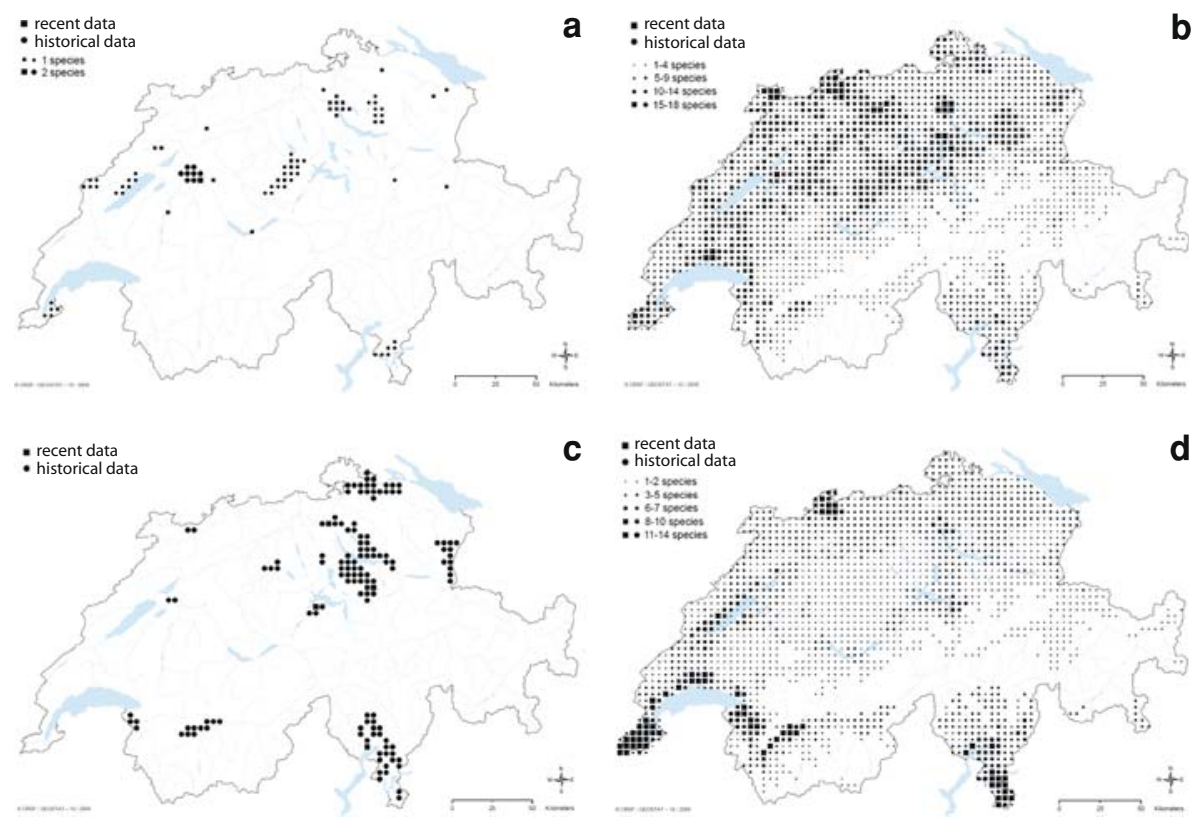

Fig. 2 Coincidence distribution maps of the Atlantic and Mediterranean-Atlantic plants in Switzerland. a Eu-Atlantic vascular plant species (Erica vagans, E. tetralix, Meconopsis cambrica, and Vicia orobus); b 39 Sub-Atlantic species; c Rhynchospora fusca, the only representative of the Eury-Atlantic subelement; d 22 Mediterranean-Atlantic species. Recent data: observations of the Data Centre of the Swiss Flora between 1982 and 2008. Historical data: literature and/or herbarium data collected before 1982. For more details, see "Materials and methods"

Table 2 Ecological groups of the Atlantic and Mediterranean-Atlantic elements in the Swiss flora

\begin{tabular}{lllllll}
\hline $\begin{array}{l}\text { Ecological } \\
\text { group }\end{array}$ & $\begin{array}{l}\text { Eu-Atlantic } \\
\text { spp. }(\%)\end{array}$ & $\begin{array}{l}\text { Sub-Atlantic } \\
\text { spp. }(\%)\end{array}$ & $\begin{array}{l}\text { Eury-atlantic } \\
\text { spp. }(\%)\end{array}$ & $\begin{array}{l}\text { Mediterranean- } \\
\text { Atlantic spp. (\%) }\end{array}$ & $\begin{array}{l}\text { Total } \\
\text { spp. (\%) }\end{array}$ & $\begin{array}{l}\text { All Swiss } \\
\text { spp. }(\%)\end{array}$ \\
\hline 1 & $3(75)$ & $15(38)$ & - & $8(36)$ & $26(39)$ & 18 \\
2 & - & $3(8)$ & - & - & $3(5)$ & 22 \\
3 & $3(8)$ & - & $6(28)$ & $9(14)$ & 6 \\
4 & - & $1(2.5)$ & - & $1(5)$ & $2(3)$ & 4 \\
5 & $1(25)$ & $11(28)$ & $1(100)$ & $3(13)$ & $16(24)$ & 11 \\
6 & - & $1(2.5)$ & - & $3(13)$ & $4(6)$ & 13 \\
7 & - & $5(13)$ & - & $1(5)$ & $6(9)$ & 24 \\
8 & - & - & - & - & - & 2 \\
Total & $4(100)$ & $39(100)$ & $1(100)$ & $22(100)$ & $66(100)$ & 100 \\
\hline
\end{tabular}

Symbols: 1, woodland plants; 2, orophytes; 3, low-altitude pioneers; 4, aquatic plants; 5, wetland plants; 6 , plants of low-nutrient meadows; 7, weeds or ruderals; 8, plants of nutrient-rich meadows. For more details, see "Materials and methods" and Appendix 1

the Atlantic element are analyzed separately, the domination of the woodland plants and wetland plants is maintained. The only exception is the Mediterranean-Atlantic subelement, in which the pioneer plants of the lowlands take second place. 
Table 3 Life forms of the Atlantic and Mediterranean-Atlantic elements in the Swiss flora

\begin{tabular}{llllllc}
\hline $\begin{array}{l}\text { Life } \\
\text { forms }\end{array}$ & $\begin{array}{l}\text { Eu-Atlantic } \\
\text { spp. }(\%)\end{array}$ & $\begin{array}{l}\text { Sub-Atlantic } \\
\text { spp. (\%) }\end{array}$ & $\begin{array}{l}\text { Eury-Atlantic } \\
\text { spp. (\%) }\end{array}$ & $\begin{array}{l}\text { Mediterranean- } \\
\text { Atlantic spp. (\%) }\end{array}$ & $\begin{array}{l}\text { Total spp. } \\
(\%)\end{array}$ & $\begin{array}{l}\text { All Swiss } \\
\text { spp. (\%) }\end{array}$ \\
\hline $\mathrm{Ph}$ & $1(25)$ & $3(8)$ & - & $3(14)$ & $7(11)$ & 8 \\
$\mathrm{Ch}$ & $1(25)$ & $8(21)$ & - & $2(9)$ & $11(17)$ & 10 \\
$\mathrm{H}$ & $2(50)$ & $15(38)$ & $1(100)$ & $5(23)$ & $23(35)$ & 41 \\
$\mathrm{Geo}$ & - & $5(13)$ & - & $8(36)$ & $13(20)$ & 15 \\
$\mathrm{Hyd}$ & - & $2(5)$ & - & - & $2(3)$ & 2 \\
$\mathrm{Th}$ & - & $2(5)$ & - & $3(14)$ & $5(7)$ & 14 \\
Th/H & - & $4(10)$ & - & $1(4)$ & $5(7)$ & 10 \\
Total & $4(100)$ & $39(100)$ & $1(100)$ & $22(100)$ & $66(100)$ & 100 \\
\hline
\end{tabular}

$P h$ phanerophytes, $C h$ chamaephytes, $H$ hemicryptophytes, Geo geophytes, Hyd hydrophytes, Th therophytes. For more details, see "Materials and methods" and Appendix 1

The majority of the Atlantic and Mediterranean-Atlantic species (taken together) are hemicryptophytes $(35 \%)$, followed by geophytes $(20 \%)$, chamaephytes $(17 \%)$, and phanerophytes (11\%) (Table 3). Poorly represented are the therophytes (five species), thero/ hydrophytes (five species), and hydrophytes (two species). In the Mediterranean-Atlantic subelement, the geophytes are the best represented category (eight species, 36\%), and there are no hydrophytes in this group.

\section{Conservation status}

Table 4 shows the conservation status of the investigated species in Switzerland expressed in the IUCN red list categories. More than $56 \%$ of the Atlantic and Mediterranean-Atlantic species are so-called "red list species" (categories RE, CR, EN, VU): 23\% are critically endangered (CR), $15 \%$ are endangered (EN), and $15 \%$ are vulnerable (VU). Two species are regionally extinct (RE). Near threatened (NT) and least concerned (LC) species represent $43 \%$. There are no data available for one species (DD) (see also Appendix 1).

Table 4 Red list categories of the Atlantic and Mediterranean-Atlantic elements in the Swiss flora

\begin{tabular}{llllllr}
\hline RL cat & $\begin{array}{l}\text { Eu-Atlantic } \\
\text { spp. }(\%)\end{array}$ & $\begin{array}{l}\text { Sub-Atlantic } \\
\text { spp. }(\%)\end{array}$ & $\begin{array}{l}\text { Eury-Atlantic } \\
\text { spp. }(\%)\end{array}$ & $\begin{array}{l}\text { Mediterranean- } \\
\text { Atlantic spp. }(\%)\end{array}$ & $\begin{array}{l}\text { Total } \\
\text { spp. }(\%)\end{array}$ & $\begin{array}{l}\text { All Swiss } \\
\text { spp. }(\%)\end{array}$ \\
\hline RE & - & $1(2.5)$ & - & $1(5)$ & $2(3)$ & 2 \\
CR & $2(50)$ & $9(23)$ & - & $4(18)$ & $15(23)$ & 5 \\
EN & $1(25)$ & $5(13)$ & $1(100)$ & $3(14)$ & $10(15)$ & 10 \\
VU & $1(25)$ & $5(13)$ & - & $4(18)$ & $10(15)$ & 14 \\
NT & - & $9(23)$ & - & $6(27)$ & $15(23)$ & 14 \\
LC & - & $9(23)$ & - & $4(18)$ & $13(20)$ & 49 \\
DD & - & $1(2.5)$ & - & - & $1(1)$ & 6 \\
Total & $4(100)$ & $39(100)$ & $1(100)$ & $22(100)$ & $66(100)$ & 100 \\
RL-species & $4(100)$ & $20(51)$ & $1(100)$ & $12(55)$ & $37(56)$ & 32 \\
\hline
\end{tabular}

For more details, see "Materials and methods" and Appendix 1 


\section{Discussion}

The allocation of species to floristic elements is a very complex process and there is still no consensus in the choice of the best criteria for such chorological divisions and delimitations (Schmid 1945; Preston and Hill 1997; Born et al. 2007). As a result, no authors or works to date have assigned all the European plants to floristic elements. Preston and Hill (1997) stated that grouping species into floristic elements by the visual inspection of maps or distributional data should be replaced completely by computational methods. However, synthesized and digitalized distributional data for the overwhelming majority of European vascular plants (ca. 80\%) are still unavailable (Finnie et al. 2007). This embarrassing situation has resulted mainly from the so-called "Wallacean shortfall", so named by Lomolino and Heaney (2004), which refers to our inadequate knowledge about the distribution of a given taxon (Whittaker et al. 2005; Kozlowski 2008). The list of Roisin (1969) suffers inevitably from the "Wallacean shortfall". An example is the listing of Isoëtes histrix as Sub-Atlantic, the species is now known, however, from many more Mediterranean sites (thus it is probably a Mediterranean-Atlantic taxon).

The list of Roisin (1969) and all the other lists published so far also suffer from the "Linnean shortfall", and almost certainly underestimate the total number of species in the Atlantic floristic element. The Linnean shortfall refers to our extremely limited knowledge of the overall species number, not only at the global level but also at the continental and local levels (Brown and Lomolino 1998). For example, Roisin (1969) omitted from his list all endemic species found in the United Kingdom, doubting their taxonomic status, as well as all species of critical genera such as Sorbus, Hieracium, Rubus, and Taraxacum (Appendix S1). The Linnean shortfall explains also why even hybrid taxa can be found in the Swiss Atlantic species list (e.g. Hypericum $\times$ desetangsii treated by Roisin as a species H. desetangsi, see Appendix S1). Furthermore, the Roisin list of Atlantic plant species and all the other lists published so far are taking into account almost exclusively their distributions (chorology). Schmid (1945) and Jäger (1968, 1970) proposed that biogeographers should join in a natural floristic element not only species of the same distribution but also of the same ecology, the same growing rhythm and perhaps of the same origin. This complex approach is, however, highly controversial.

As a consequence of the deficiencies mentioned, new appraisal and a comprehensive statement of the conservation status of all Atlantic plant species in Europe are currently lacking. The Atlantic plant list of Roisin (1969) (see Appendix S1), although created by inspecting maps, herbaria, and literature data, is the most complete and the most recently published list (although it is almost 40 years old!). Furthermore, because of its methodology and scientific rigor, the Roisin list is the only biogeographically complete and thus internationally accepted list (Hopkins and Buck 1995). There are some examples of more recent lists, but they do not cover the entire European flora (e.g., Preston and Hill 1997). Several other lists and data banks do not take into account the global distributions of the listed species (e.g., www.floraweb.de for Germany).

The Swiss flora comprises 66 Atlantic and Mediterranean-Atlantic taxa, which represent barely $2 \%$ of all vascular plants growing in Switzerland. They are taxonomically and ecologically highly diverse. Only four species growing in Switzerland belong to the EuAtlantic subelement (4\% of all Eu-Atlantic European plants). Among them, only Vicia orobus can be classified with certainty as a native element of the Swiss flora. With only one known population (Jura, Les Verrières) and ca. 50-100 individuals, it is currently critically endangered in Switzerland. Erica vagans is known from only one population growing close to Geneva (Bois de Jussy, next to Présinge, not confirmed in recent years), but it is 
thought to be introduced there (Hegi 1975). Two further Eu-Atlantic species are relatively new to the Swiss flora: Erica tetralix was probably introduced after World War I in Mettelimoos next to Lucerne and later also in 1-2 peat-bog complexes (Hess et al. 1980); and Meconopsis cambrica has been found at several sites across the Swiss Plateau and Tessin in recent years, probably having escaped from cultivation.

Our study confirms the Sub-Atlantic phytogeographic position of Switzerland shown in Fig. 1. The Sub-Atlantic group is represented in Switzerland by $44 \%$ of all European plants of this subelement. This is also supported by the relatively dense occurrences of these plants in all lowland regions across the Swiss Plateau and Tessin (Fig. 2b). Although a very alpine country, Switzerland has a high percentage of Mediterranean-Atlantic species (27\% of all the European species in this group). This phenomenon can be explained by the proximity of southern Switzerland to the Mediterranean region and is emphasized in Fig. 2d, showing the higher concentrations of these plants in Tessin, around Lake Geneva, and in very dry, warm Valais. The higher concentrations of MediterraneanAtlantic species around Zürich and at the exit of the Gotthard tunnel might be explained by the predominance of disturbed human habitats, suitable for warmth-preferring and pioneer plants.

The Atlantic element of the European flora is mainly composed of littoral and heathland plants (43\% of all 195 taxa; Appendix S1), and therefore their growth habitats are almost completely lacking in Switzerland. In the Swiss flora, the dominant ecological groups are orophytes and plants related to agriculture and dense settlements, such as weeds and ruderals (Moser et al. 2002; Table 2). In contrast, the Atlantic and Mediterranean-Atlantic species mainly grow in Switzerland in woodlands and wetlands (63\% of all 66 taxa). The life form distributions shown in Table 3 support these data. The phanerophytes and chamaephytes together constitute $27 \%$ of all the Atlantic/Mediterranean-Atlantic taxa in Switzerland.

The Atlantic/Mediterranean-Atlantic element occuring in Switzerland is a very threatened plant group (56\% of these species are red list species, Table 4). Two species are regionally extinct: Isoëtes echinospora (Sub-Atlantic wetland plant) and Filago gallica (Mediterranean-Atlantic weedy species). The most imperilled ecological group is the wetland plants. Many of them are critically endangered (CR) in Switzerland and are on the brink of extinction, e.g., Apium repens, Elatine hexandra, Galium saxatile, Pilularia globulifera, and Scrophularia auriculata (Appendix 1). In contrast, the woodland species are less endangered. In fact, many of them (especially the Sub-Atlantic taxa, but also several Mediterranean-Atlantic taxa) are widespread inhabitants of Swiss forests. The only exception is the Eu-Atlantic group, among which Vicia orobus merits the highest conservation priority.

The study by Preston (2007) shows a similar situation for the British Isles, where in contrast, plants with eastern ranges are a particularly threatened group. How much importance should be attached, however, to the conservation of edge-of-range populations, especially for species with greater frequency elsewhere? It is supposed that plant populations adapted for life at a margin will prove to be pre-adapted to withstand the alterations that may be brought about, e.g., by a climate change (Crawford 2008). Furthermore, analyses of range collapse reveals that the last existing populations of many species were located along the periphery and not in the center of their historic range (Lomolino and Channell 1995, 1998). Thus, peripheral sites in Switzerland may represent in the future critical refugia for many endangered Atlantic and Mediterranean-Atlantic plant species. 


\section{Conclusions}

Our study clearly demonstrates that the Atlantic flora of Europe requires a new biogeographical appraisal. The most comprehensive list is now 40 years old (Roisin 1969) and due to taxonomic changes and advances in chorological knowledge it is inevitably outdated. The Swiss flora comprises 66 Atlantic and Mediterranean-Atlantic taxa, which are taxonomically highly diverse. Switzerland contains $44 \%$ of all European Sub-Atlantic plants, confirming the Sub-Atlantic geographical position of Switzerland. Only one EuAtlantic species growing in Switzerland, Vicia orobus, can be classified with certainty as native. This species is critically endangered and merits the highest conservation priority. Although a very alpine country, Switzerland has a relatively large number of Mediterranean-Atlantic species. The Atlantic and Mediterranean-Atlantic plants are a very threatened group in Switzerland, with wetland plants the most imperilled ecological group.

Acknowledgments We would like to thank Beat Bäumler and his group from the Data Centre of the Swiss Flora (CRSF, Geneva) for the preparation of the distribution maps. We wish to thank Benoît Clément and Susanne Bollinger from the Botanical Garden of the University of Fribourg (Switzerland) for their assistance during the manuscript preparation. We are also indebted to the Franklinia Foundation for its engagement and valuable support.

\section{Appendix 1}

The list and its division follows Roisin (1969) and is based on the works of Braun-Blanquet (1924), Steffen (1935), des Abbayes (1945), Fournier (1946), Walter (1954), des Darimont et al. (1962), and Dupont (1962). RL, IUCN red list categories (Moser et al. 2002). See Table 5.

Table 5 Atlantic and Mediterranean-Atlantic elements in the Swiss flora

\begin{tabular}{|c|c|c|c|c|}
\hline Taxon & Family & RL & EG & $\mathrm{LF}$ \\
\hline \multicolumn{5}{|l|}{ Eu-Atlantic (4 spp.) } \\
\hline Erica vagans $\mathrm{L}$. & Ericaceae & CR & 1 & $\mathrm{Ph}$ \\
\hline Erica tetralix L.* & Ericaceae & $\mathrm{EN}$ & 5 & $\mathrm{Ch}$ \\
\hline Meconopsis cambrica (L.) Vig.* & Papaveraceae & VU & 1 & $\mathrm{H}$ \\
\hline Vicia orobus DC. & Fabaceae & $\mathrm{CR}$ & 1 & $\mathrm{H}$ \\
\hline \multicolumn{5}{|l|}{ Sub-Atlantic (39 spp.) } \\
\hline Aira praecox $\mathrm{L}$. & Poaceae & DD & 7 & Th \\
\hline Anagallis tenella (L.) L. & Primulaceae & CR & 5 & Th \\
\hline Apium repens (Jacq.) Lag. & Apiaceae & $\mathrm{CR}$ & 5 & $\mathrm{H}$ \\
\hline Carduus tenuiflorus Curtis* & Asteraceae & CR & 7 & $\mathrm{Th} / \mathrm{H}$ \\
\hline Carex strigosa Huds. & Cyperaceae & NT & 1 & $\mathrm{H}$ \\
\hline Chrysosplenium oppositifolium L. & Saxifragaceae & NT & 1 & $\mathrm{H}$ \\
\hline Cirsium tuberosum (L.) All. & Asteraceae & VU & 5 & Geo \\
\hline Coincya cheiranthos (Vill.) Greuter \& Burdet* & Brassicaceae & CR & 3 & $\mathrm{Th} / \mathrm{H}$ \\
\hline Cytisus scoparius (L.) Link & Fabaceae & $\mathrm{LC}$ & 2 & $\mathrm{Ph}$ \\
\hline Digitalis purpurea L.* & Scrophulariaceae & NT & 1 & $\mathrm{H}$ \\
\hline Elatine hexandra (Lapierre) DC. & Elatinaceae & CR & 5 & Hyd \\
\hline Galeopsis segetum Neck. & Lamiaceae & $\mathrm{EN}$ & 7 & $\mathrm{Th} / \mathrm{H}$ \\
\hline
\end{tabular}


Table 5 continued

\begin{tabular}{|c|c|c|c|c|}
\hline Taxon & Family & RL & EG & LF \\
\hline Galium saxatile $\mathrm{L}$. & Rubiaceae & $\mathrm{CR}$ & 5 & $\mathrm{Ch}$ \\
\hline Genista pilosa $\mathrm{L}$. & Fabaceae & $\mathrm{VU}$ & 1 & $\mathrm{Ch}$ \\
\hline Helleborus foetidus $\mathrm{L}$. & Ranunculaceae & $\mathrm{LC}$ & 1 & $\mathrm{Ch}$ \\
\hline Helleborus viridis $\mathrm{L}$. & Ranunculaceae & NT & 1 & $\mathrm{H}$ \\
\hline Hypericum pulchrum $\mathrm{L}$. & Hypericaceae & $\mathrm{VU}$ & 1 & $\mathrm{H}$ \\
\hline Hypericum $\times$ desetangsii Lamotte & Hypericaceae & $\mathrm{LC}$ & 5 & $\mathrm{H}$ \\
\hline Ilex aquifolium $\mathrm{L}$. & Aquifoliaceae & $\mathrm{LC}$ & 1 & $\mathrm{Ph}$ \\
\hline Isoëtes echinospora Durieu & Isoëtaceae & $\mathrm{RE}$ & 4 & Hyd \\
\hline Linaria repens (L.) Mill. & Scrophulariaceae & VU & 7 & $\mathrm{H}$ \\
\hline Linaria supina (L.) Chaz.* & Scrophulariaceae & EN & 3 & $\mathrm{Ch}$ \\
\hline Lonicera periclymenum $\mathrm{L}$. & Caprifoliaceae & NT & 1 & $\mathrm{Ph}$ \\
\hline Lysimachia nemorum $\mathrm{L}$. & Primulaceae & $\mathrm{LC}$ & 1 & $\mathrm{Ch}$ \\
\hline Narcissus pseudonarcissus L. & Amaryllidaceae & NT & 2 & Geo \\
\hline Ornithopus perpusillus L. & Fabaceae & $\mathrm{CR}$ & 7 & $\mathrm{Th} / \mathrm{H}$ \\
\hline Orobanche rapum-genistae Thuill. & Orobanchaceae & NT & 1 & Geo \\
\hline Pedicularis sylvatica $\mathrm{L}$. & Scrophulariaceae & VU & 5 & $\mathrm{H}$ \\
\hline Pilularia globulifera $\mathrm{L}$. & Marsiliaceae & $\mathrm{CR}$ & 5 & Geo \\
\hline Pinguicula grandiflora Lam. & Lentibulariaceae & EN & 2 & $\mathrm{H}$ \\
\hline Polygala calcarea F. W. Schultz & Polygalaceae & EN & 6 & $\mathrm{Ch}$ \\
\hline Polygala serpyllifolia Hosé & Polygalaceae & $\mathrm{LC}$ & 5 & $\mathrm{Ch}$ \\
\hline Potentilla sterilis (L.) Garcke & Rosaceae & $\mathrm{LC}$ & 1 & $\mathrm{H}$ \\
\hline Primula acaulis (L.) L. & Primulaceae & $\mathrm{LC}$ & 1 & $\mathrm{H}$ \\
\hline Pulmonaria montana Lej. & Boraginaceae & NT & 1 & $\mathrm{H}$ \\
\hline Sagina subulata (Sw.) C. Presl & Caryophyllaceae & EN & 3 & $\mathrm{Ch}$ \\
\hline Scrophularia auriculata $\mathrm{L}$. & Scrophulariaceae & $\mathrm{CR}$ & 5 & $\mathrm{H}$ \\
\hline Senecio aquaticus Hill & Asteraceae & NT & 5 & $\mathrm{H}$ \\
\hline Teucrium scorodonia $\mathrm{L}$. & Lamiaceae & $\mathrm{LC}$ & 1 & Geo \\
\hline \multicolumn{5}{|l|}{ Eury-Atlantic (1 sp.) } \\
\hline Rhynchospora fusca (L.) W. T. Aiton & Cyperaceae & EN & 5 & $\mathrm{H}$ \\
\hline \multicolumn{5}{|l|}{ Mediterranean-Atlantic (22 spp.) } \\
\hline Agropyron pungens (Pers.)Roem. \& Schult. & Poaceae & NT & 3 & Geo \\
\hline Asphodelus albus Mill. & Liliaceae & VU & 6 & $\mathrm{H}$ \\
\hline Asplenium billotii F. W. Schultz & Polypodiaceae & $\mathrm{CR}$ & 3 & $\mathrm{H}$ \\
\hline Asplenium foreziense Magnier & Polypodiaceae & $\mathrm{CR}$ & 3 & $\mathrm{H}$ \\
\hline Baldellia ranunculoides (L.) Parl. & Alismataceae & $\mathrm{CR}$ & 4 & Geo \\
\hline Blackstonia perfoliata (L.) Huds. & Gentianaceae & $\mathrm{VU}$ & 5 & Th \\
\hline Carex punctata Gaudin & Cyperaceae & NT & 5 & $\mathrm{H}$ \\
\hline Daphne laureola L. & Thymelaeaceae & $\mathrm{LC}$ & 1 & $\mathrm{Ph}$ \\
\hline Filago gallica $\mathrm{L}$. & Asteraceae & $\mathrm{RE}$ & 7 & Th \\
\hline Fritillaria meleagris $\mathrm{L}$. & Liliaceae & EN & 5 & Geo \\
\hline Hedera helix $\mathrm{L}$. & Araliaceae & $\mathrm{LC}$ & 1 & $\mathrm{Ph}$ \\
\hline Helianthemum apenninum (L.) Mill. & Cistaceae & VU & 3 & $\mathrm{Ch}$ \\
\hline Hypericum androsaemum L.* & Hypericaceae & NT & 1 & $\mathrm{Ch}$ \\
\hline
\end{tabular}


Table 5 continued

\begin{tabular}{lllll}
\hline Taxon & Family & RL & EG & LF \\
\hline Iris foetidissima L.* & Iridaceae & EN & 6 & Geo \\
Luzula forsteri (Sm.) DC. & Juncaceae & NT & 1 & H \\
Ornithogalum pyrenaicum L. & Liliaceae & NT & 1 & Geo \\
Orobanche hederae Duby & Orobanchaceae & NT & 1 & Geo \\
Ruscus aculeatus L. & Liliaceae & LC & 1 & Ph \\
Sedum rubens L. & Crassulaceae & VU & 3 & Th \\
Tamus communis L. & Dioscoreaceae & LC & 1 & Geo \\
Umbilicus rupestris (Salisb.) Dandy & Crassulaceae & CR & 3 & Geo \\
Verbascum pulverulentum Vill. & Scrophulariaceae & EN & 6 & Th/H \\
\hline
\end{tabular}

* Taxa that have spread in Switzerland since the year 1500. EG Ecological group affiliations (Moser et al. 2002): (1) woodland plants; (2) orophytes; (3) low-altitude pioneers; (4) aquatic plants; (5) wetland plants; (6) plants of low-nutrient meadows; (7) weeds or ruderals; (8) plants of nutrient-rich meadows. $L F$ life forms (Raunkiaer 1934; adapted for Switzerland by Landolt 1977): $P h$ phanerophytes, $C h$ chamaephytes, $H$ hemicryptophytes, Geo geophytes, Hyd hydrophytes, Th therophytes

\section{References}

Allorge P (1924) Etude sur la flore et la vegetation de l'Ouest de la france. 1. A propos des espèces atlantiques de la flore française. Bull Soc Bot Fr 71:1183-1194

Born J, Linder HP, Desmet P (2007) The greater cape floristic region. J Biogeogr 34:147-162. doi:10.1111/ j.1365-2699.2006.01595.x

Braun-Blanquet J (1923) L'Origine et le développement des flores dans le Massif central de France, avec aperçu sur les migrations des flores dans l'Europe sud-occidentale. Beer et Cie, Zürich

Braun-Blanquet J (1928) Pflanzensoziologie-Grundzüge der Vegetationskunde. Springer, Berlin

Braun-Blanquet J (1953) Irradiations européennes dans la végétation de la Kroumirie. Plant Ecol 4:182-194. doi:10.1007/BF00297018

Brown JH, Lomolino MV (1998) Biogeography. Sinauer Press, Sunderland

Cook CDK (1983) Aquatic plants endemic to Europe and the Mediterranean. Bot Jahrb Syst 103:539-582

Crawford RMM (2000) Ecological hazards of oceanic environments. New Phytol 147:257-281. doi:10.1046/ j.1469-8137.2000.00705.x

Crawford RMM (2008) Plants at the margin: ecological limits and climate change. Cambridge University Press, Cambridge

Czeczott H (1926) The Atlantic element in the flora of Poland. Bull Intern Acad Polonaise Série B Sci Nat 1926:361-407

Dahl E (1998) The phytogeography of northern Europe (British Isles, Fennoscandia and adjacent areas). Cambridge University Press, Cambridge

Darimont F, Duvigneaud J, Lambinon J (1962) Le Massif Armoricain. Excursion de la Société Botanique de Liège. Lejeunia 9:1-63

de Candolle AP (1808) Rapports sur des voyages botaniques et agronomiques dans les départements de l'Ouest et du Sud-Ouest de la France. Mémoires de la Société agronomique du département de la Seine $10: 21-24$

des Abbayes H (1945) L'élément atlantique de la flore vasculaire armoricaine. Bull Soc Sci Bretagne 20: $55-70$

Drude O (1892) Carte botanique de l'Europe occidentale. In: Massart J (ed) Esquisse de la géographie botanique de la Belgique. Receuil de l'Institut Botanique Léo Errera, Bruxelles, pp 1-332

Duckworth JC, Bunce RGH, Malloch AJC (2000) Vegetation gradients in Atlantic Europe: the use of existing phytosociological data in preliminary investigations on the potential effects of climate change on British vegetation. Glob Ecol Biogeogr 9:187-199. doi:10.1046/j.1365-2699.2000.00161.x

Dupont P (1962) La Flore Atlantique Européenne. Documents pour les cartes des productions végétales Faculté des Sciences, Toulouse

EEA (2005) Biogeographical regions. European Environmental Agency, Copenhagen 
ETCBD (2006) The indicative map of the European biogeographical regions: methodology and development. European Topic Centre on Biological Diversity, Paris

Finnie TJR, Preston CD, Hill MO, Uotila P, Crawley MJ (2007) Floristic elements in European vascular plants: an analysis based on Atlas Florae Europaeae. J Biogeogr 34:1848-1872. doi:10.1111/j.13652699.2007.01750.x

Flahault C (1901) La Flore et la végétation de la France. In: Coste H (ed) Flore descriptive et illustré de la France, de la Corse et des contrées limitrophes. A. Blanchard, Paris

Fournier P (1946) Les quatre flores de la France. Corse comprise, Lechevalier

Hegi G (1975) Illustrierte Flora von Mittel-Europa. Band V. Teil 3. Paul Parey, Berlin

Hess HE, Landolt E, Hirzel R (1980) Flora der Schweiz und angrenzender Gebiete. Birkhäuser, Basel

Hopkins JJ, Buck AL (1995) The habitats directive atlantic biogeographical region. Report of Atlantic biogeographical workshop. JNCC Report, No. 247, Edinburgh, Scotland, 13-14 October 1994, pp19-21

ISFS (2005) Index synonimique de la flore Suisse et territoires limitrophes. Documenta Floristicae Helvetiae, No 2. CRSF/ZDSF, Genève

IUCN (2001) IUCN red list categories and criteria: Version 3.1. Species Survival Commission, IUCN, Gland/Cambridge

Jäger EJ (1968) Die pflanzengeographische Ozeanitätsgliederung der Holarktis und die Ozeanitätsbindung der Pflanzenareale. Feddes Repert 79:157-335

Jäger EJ (1970) Charakteristische Typen mediterran-mitteleuropäischer Pflanzenareale. Feddes Repert 81:67-92

Kozlowski G (2008) Is the global conservation status assessment of a threatened taxon a utopia? Biodivers Conserv 17:445-448. doi:10.1007/s10531-007-9278-Z

Kozlowski G, Jones RA, Vuille-Nicholls F-L (2008) Biological flora of the Central Europe: Baldellia ranunculoides (Alismataceae). Perspect Plant Ecol Evol Syst 10:109-142. doi:10.1016/j.ppees.2007. 12.003

Krausch H-D (1985) Ozeanische Florenelemente in aquatischen Pflanzengesellschaften der D.D.R. Vegetatio 59:193-198. doi:10.1007/BF00055690

Landolt E (1977) Ökologische Zeigerwerte zur Schweizer Flora. Veroffentlichungen Geobotanischen Instituts ETH Zurich 64:1-208

Lomolino MV, Channell R (1995) Splendid isolation: patterns of geographic range collapse in endangered mammals. J Mammal 76:335-347. doi:10.2307/1382345

Lomolino MV, Channell R (1998) Range collapse, re-introductions, and biogeographic guidelines for conservation. Conserv Biol 12:481-484. doi:10.1046/j.1523-1739.1998.97201.x

Lomolino MV, Heaney LR (eds) (2004) Frontiers of biogeography: new directions in the geography of nature. Sinauer Associates, Sunderland

Matthews JR (1937) Geographical relationships of the British flora. J Ecol 25:1-90. doi:10.2307/2256326

Meusel H, Jäger E, Weinert E (1965) Vergleichende Chorologie der zentraleropäischen Flora, vol 1. Gustav Fischer, Jena

Moser DM, Bäumler B, Gygax A, Palese R, Wyler N (2002) Rote Liste der gefährdeten Arten der Schweiz. Farn- und Blütenpflanzen. BUWAL, Bern

Ojeda F, Arroyo J, Marañon T (1998) The phytogeography of European and Mediterranean heath species (Ericoideae, Ericaceae): a quantitative analysis. J Biogeogr 25:165-178. doi:10.1046/j.1365-2699.1998. 251141.x

Pietsch W (1985) Chorologische Phänomene in Wasserpflanzengesellschaften Mitteleuropas. Vegetatio 59:97-109. doi:10.1007/BF00055679

Preston CD (2007) Which vascular plants are found at the northern or southern edges of their European range in the British Isles? Watsonia 26:253-269

Preston CD, Arnold HR (2006) The Mediterranean-Atlantic and Atlantic elements in the Cornish flora. In: Leach SJ, Page CN, Peytoureau Y, Sanford MN (eds) Botanical links in the Atlantic arc. BSBI/English Nature, London, pp 41-57

Preston CD, Hill MO (1997) The geographical relationships of British and Irish vascular plants. Bot J Linn Soc 124:1-120

Raunkiaer C (1934) The life-forms of plants and statistical plant geography. Oxford University Press, London

Rivas-Martinez S (1990) Bioclimatology and biogeography of West Europe. Climate and global change. In: Duplessey VC, Poms A, Fantecli R(eds) Proceedings of European school of climatology and natural hazards, European Commission, Brussels, pp 225-246

Roisin P (1969) Le domaine phytogéographique atlantique d'Europe. Editions J. Duculot, Gembloux

Schmid E (1945) Die “atlantische” Flora, eine kritische Betrachtung. Ber Geobot Inst Rubel 1944:124-140 
Steffen H (1935) Beiträge zur Begriffsbildung und Umgrenzung einiger Florenelemente Europas. Beih Bot Centrbl 53:330-404

Takhtajan A (1986) Floristic regions of the world. University of California Press, Berkeley

Tutin TG, Burges NA, Chater AO, Edmondson JR, Heywood VH, Moore DM, Valentine DH, Walters SM, Webb DA (1993) Flora Europaea, 5 Vols. Cambridge University Press, Cambridge

Walter H (1954) Arealkunge. Grundlagen der Pflanzenverbreitung, Teil II. Ulmer, Stuttgart

Welten M, Sutter R (1982) Verbreitungsatlas der Farn- und Blütenpflanzen der Schweiz. Birkhäuser, Basel

Whittaker RJ, Araujo MB, Jepson P, Ladle RJ, Watson JEM, Willis KJ (2005) Conservation biogeography: assessment and project. Divers Distrib 11:3-23. doi:10.1111/j.1366-9516.2005.00143.X 